\title{
Sinos River Hydrographic Basin: urban occupation, industrialization and environmental memory
}

\author{
M. F. Nunes ${ }^{a *}$, J. A. S. Figueiredo ${ }^{b}$ and A. L. C. Rocha ${ }^{a}$ \\ ${ }^{a}$ Grupo de Pesquisa em Metropolização e Desenvolvimento Regional, Programa em Diversidade Cultural e \\ Inclusão Social, Universidade Feevale, Estrada RS 239, 2755, CEP 93352-000, Novo Hamburgo, RS, Brazil \\ ${ }^{\mathrm{b}}$ Grupo de Pesquisa Ambiente e Sociedade, Programa em Qualidade Ambiental, Universidade Feevale, \\ Estrada RS 239, 2755, CEP 93352-000, Novo Hamburgo, RS, Brazil \\ *e-mail: marga.nunes@feevale.br
}

Received: January 17, 2015 - Accepted: May 20, 2015 - Distributed: November 30, 2015

\begin{abstract}
This article presents an analysis of the process of industrialization and urbanization of the Sinos Valley in Rio Grande do Sul state, Brazil, starting from the establishment of leather goods and footwear manufacturing in the region during the 19th century when tanneries and factories producing footwear and/or components for footwear began to appear, and with special attention to aspects related to the environmental impact on the Sinos river hydrographic basin. The article is based on both bibliographic and documentary research and also draws on biographical narratives of workers with links to the leather goods and footwear industry obtained using ethnographic method. It was found that contemporary environmental conflicts emerge from within a memory of work and an environmental memory in which the factories, the unplanned urbanization, and the utilization of water and other natural resources form a chain of significance. Significance that precludes any form of fragmented analysis that isolates any of these aspects from the others: the economic, socio-historic, cultural, political, or the environmental.
\end{abstract}

Keywords: urban waters, work, environmental memory, tannery, hydrographic basin.

\section{Bacia Hidrográfica do Rio dos Sinos: ocupação urbana, industrialização e memória ambiental.}

\section{Resumo}

O artigo aborda o processo de industrialização e urbanização do Vale do Rio dos Sinos/Rio Grande do Sul/Brasil, desde a implantação da indústria coureiro-calçadista na região, no século XIX, com o surgimento dos curtumes e das fábricas de calçados e/ou componentes para calçados, destacando, em especial, os aspectos ligados ao impacto ambiental na Bacia Hidrográfica dos Sinos. Faz-se uso de pesquisa bibliográfica e documental, além da exposição de narrativas biográficas de trabalhadores ligados à indústria coureiro-calçadista, obtidas por meio do método etnográfico. Verifica-se que os conflitos ambientais contemporâneos emergem do interior de uma memória do trabalho e de uma memória ambiental, nas quais a fábrica, a ocupação urbana desordenada, o uso da água e dos demais recursos naturais formam um encadeamento de sentido que impede qualquer análise fragmentada que isole um destes aspectos: o econômico, o socio-histórico, o cultural, o político, o ambiental.

Palavras-chave: águas urbanas, trabalho, memória ambiental, curtume, bacia hidrográfica.

\section{Introduction}

The arrival of German immigrants in the South of Brazil over the course of the nineteenth century is generally taken as the trigger for the process of industrialization and urbanization of Brazil's southernmost state, Rio Grande do Sul. This article is written with the objective of constructing a picture of this process that acknowledges "environmental memory" (Devos, 2007; Devos et al., 2010) and so we have chosen to explore alternative forms of narrating the migration of populations leading to the peopling of Sinos River Hydrographic Basin and formation of the workforce

in the surrounding areas. ${ }^{1}$ We have therefore divided the article into three sections: 1 . Socio-historic aspects of

\footnotetext{
1 The Sinos River hydrographic basin has an area of approximately $3,800 \mathrm{~km}^{2}$, subdivided politically into 32 municipal administrations, following a $190 \mathrm{~km}$ water course from the spring in the municipality of Caraa to the falls in Canoas (COMITESINOS, 2015). The municipalities with the most important settlements are Campo Bom, Igrejinha, Taquara, Novo Hamburgo, EstânciaVelha, São Leopoldo and Sapucaia do Sul. For the purposes of this article, we will restrict our analysis to the part of the basin known locally as the "lowlands", with a special focus on the town of Novo Hamburgo and its surrounding area.
} 
occupation of the land, in which we cover the ways in which the hydrographic basin was occupied over the course of the processes of settlement, foundation and growth of the most important towns and cities in the Sinos Valley, with special focus on the cities of Novo Hamburgo and São Leopoldo; 2 . The conflicts arising from occupation and the use of natural resources, giving prominence to certain facts that illustrate the start of the process of industrialization and urbanization and others that are part of contemporary history. 3. The environment and public participation in the Vale do Sinos - by way of conclusions.

\section{Socio-historic Aspects of the Occupation}

The working processes that the German immigrants brought with them when they arrived in the Sinos valley had their roots in their traditional models of utilization of natural resources in their territories of origin. Evidence of this can be found in the fact that territorial occupation of the area where the city of Novo Hamburgo is today, as part of one of the sub-districts of São Leopoldo, began with commercial establishments and trading houses that were the origins of the settlement that became the Hamburgo Velho.

Sited on the margins of the Sinos river, Hamburgo Velho was a corridor town (Rocha, 1994) that grew up as an integral part of the caminho das tropas, which were trails used for trade and for driving livestock, situated in the Northeast of Rio Grande do Sul state, descending the Serra Gaúcha range in the direction of the state capital Porto Alegre. The caminho das tropas forked at the site of the settlement of Hamburgo Velho, with one branch linking the region directly to the city of Porto Alegre, along the route that today is served by the BR 116 highway system, connecting Porto Alegre to the mountain region; while the other branch led West, in the direction of the Rio Caí Basin, which was a strategic location for the establishment of trading houses that conducted the exchange of goods between the mountain region and the colonies and the agricultural and livestock production centers in the state capital.

We can therefore consider that during the period from the end of the nineteenth century to the threshold of the twentieth century, footwear manufacture (which began with Pedro Adams Filho and Arthur Haas) and production of leather articles were part of Hamburgo Velho's civilizing mission, transforming it into an commercial emporium for the goods produced by the immigrant German families that had settled in the region. Later, the political elites would promote the region as the state's industrial heart, in a process to co-opt the local political leaders and aristocracy (Schemes, 2006).

There is evidence that the missionary, economic and administrative activities carried out by the German influx to the Sinos River valley were predicated on the stereotypical view of the European colonization model from the Brazilian imperial period, by which the "native" population of Rio Grande do Sul was unable to make fruitful use of the area's natural resources using its traditional agro-pastoral model. This provides an insight into what became the prevailing image of Novo Hamburgo: "[...] a center of industry and of culture, of respect for order, of obedience to law and of fulfillment of civic duties" (Petry, 1944, p. 14, our translation), ${ }^{2}$ as reported in the middle of the twentieth century by Leopoldo Petry.

There was therefore a contrast by which the perceived decadence of the old colonial economy based on its agro-pastoral model, of its outmoded methods of utilization of the natural resources in South Brazil and the resultant creation of poverty and land dispossession (Robequain and Gourou, apud Balandier, 1993, p. 111), leading to uprooting of traditional populations from their ancient territories, is compared to the German colonists of this part of Rio Grande do Sul and their

[...] firm and healthy guidance [...] passed down from parents to their children and grandchildren, that today forms an honorable tradition intimately relatedto economic, social, civic and religious development (Petry, 1944, p. 14, our translation).

The existing territory therefore underwent a process of recolonization, with the old hierarchical traditions of the region's agro-pastoral model superimposed over another model, an urban-industrial model, which is also European, but is possessed of a purer sense of metropolitan life than the preexisting Iberian model. As a result, new names for places emerge alongside the old territorial names:

As you know, the settlement that formed the original heart of the town of Novo Hamburgo was known as Hamburg-Berg right from its founding, which means Hamburgers' Hill. [...] The region of Sapiranga was called 'Leonerhof' - Leões' Place, because there was a family called Leão living there. [...] Dois Imãos was 'Baumschneiss' and Bom Jardim was 'Berghahnerschneiss' [...] (Petry, 1944, p. 14, our translation).

Almost a century later, this slow process would almost always be retold in narratives with a heroic tone by officials:

[...] wherever they founded a settlement in the virgin forest, as that settlement grew up around a church, a school or a trading house, they would name it after the first tradesman or resident of note. (Petry, 1944, p. 15, our translation)

We see these images as mythological derivations of the images of the "struggle for the land" in Rio Grande do Sul, which are present as the ancestral gesture of conquest of the land and the waters in the collective memory of the urban communities of Novo Hamburgo and São Leopoldo in the territory in which they are located: the Sinos valley!

There are scant references to the indigenous people who lived in the region (referred to as "indians") in the official memory of the process of conquest of the land and water resources in the Sinos region. In contrast, references to the gesture of the Portuguese conquerors and colonizers of the region and to the gesture of the German colonies are

\footnotetext{
2 This and all other italicised citations have been translated into English from sources in other languages for the purposes of this article.
} 
always in reference to the terrible condition of the tracts of land allocated to the Germans. This phenomenon is undoubtedly related to processes of "social declassification" of the Portuguese ways of working in the Sinos region and, in common with other places in the Americas, as pointed out by Quijano (2000), the indians came to be associated with a social structure of servitude and the blacks with slavery, while the image of the European is associated with paid work.

The moral force of the free colonists' industry would be able, finally, to expunge the traces of slave labor left by the imperial government on the region.

In 1825 , with the founding of the settlement, the first businesses began to appear. And more soon followed. The first industries began to develop [...] In 1829 there were eight flour mills, a soap factory, a mill for polishing stones, workshops producing goods from horn and horsehair, metalwork shops, timber mills, carpentry workshops, shoemaking, tailoring and a fledgling weaving workshop... This was the beginning of what would become an intense hive of industry. [...] Forty years of disorder, painful tragedies, terrible screams of pain and the cracking of whips on naked bodies, calcinated by the most crucifying of tortures, of murders and hatred; plots and indolence; vices and punishments - there in the same land, gouged by so much despair, were redeemed by the work of free men, already baring rich fruit, which would become the abundance of this calumniated land and its eternal salvation (Porto, 1934, p. 52, our translation).

This exaltation of the work of the immigrants contrasts strikingly with the disdain afforded to the work of the ethnic groups who preceded them. The environmental memory found in the descriptions of travelers is interwoven with the distinct values attributed the different ethnoracial groups that made up the population of Rio Grande do Sul.

We thought we were in Germany. Surveying this European settlement, it was impossible to escape a feeling of admiration, since I was immediately struck by the contrast that these places made, with their careful cultivation, their paths painstakingly cut into the cliffs, hills and forests, the small properties surrounded by deep valleys or intertwined bushes, the activity of the farmers and factory workers, with their collective prosperity enviably rivaling the state of total abandonment in which the Brazilians leave their lands, the poor state of their roads, their cabins in ruins, in short, their lack of industry, the prodigal and destructive spirit that is characteristic of them, in common with the Argentineans. My admiration was no less to witness a nation from the polar regions, here, practically in the tropics, preserving their habits, their costumes and their active lifestyle and giving rise to a generation that one day must change the face of this country (Isabelle, 2006, p. 251-252, our translation).

Other Germans who had a certain amount of capital established other more or less important enterprises such as tanneries, distilleries, timber yards, brick works and other types of manufacture, such as manioc flour and sugar, which already produce a good income for the colony, without mentioning the benefits of the trading relations with
Porto Alegre. Every week on a Tuesday the foodstuff and manufactured products produced by the small republic are taken to the capital (Isabelle, 2006, p. 253, our translation).

A group of shareholders has been assembled to fund construction of a bridge over the Sinos river and there is already talk of raising public buildings, opening new roads, constructing a steamboat (Isabelle, 2006, p. 253, our translation).

[...] the Germans do not balk at any obstacle and the word impossible does not have an equivalent in their language as it does in ours. The new generation, aspiring to the honor of figuring in the book of the immortals in shining letters, must itself cut the quill which will record its claims on the admiration of future races (Isabelle, 2006, p. 273, our translation).

The different values attributed to different ethnoracial groups help to explain the conflicts that were to occur in consequence of the territorial occupation and, over the course of the historic process, the conflicts resulting from the use of the urban space itself and the disputes that would emerge in the region's political and ideological sphere.

\section{Conflicts Arising from Occupation and use of Natural Resources}

In an effort therefore to advance a little deeper into the subject, the conflicts related to the ways in which the Sinos valley region was occupied and to the view of its land as an "idle or unproductive element" of the territory of the old province of São Pedro can be considered as part of what the political ecology espoused by Martínez-Alier (2004) calls ecological distribution conflicts. This in turn implies widening the debate on the world of work in the Sinos valley seen through the lens of territorial declassification, not only as part of the "complex designation "colonial situation" (Balandier, 1993), but also as part of the social norms that dictate the use of natural resources over time, which, via the same route, are also interlaced with factors of a cultural, economic, political and technological order (Martínez-Alier, 2004).

The forms of territorial occupation utilized by the German industrial-laborer model in the Sinos valley over the course of its environmental history are interlinked with dynamics of economics and power, i.e., they have a close relationship with conflicts that arise from disputes over control of natural resources (Martínez-Alier, 2004) and involve the different ethnoracial groups that make up the region's population.

It is interesting to note the degree of tension between blacks and Germans in the Sinos Valley, seen from the perspective of studies into the Farroupilha revolution (1835-1845). Aurelio Porto's work entitled $O$ Trabalho Alemão no Rio Grande do Sul (Porto, 1934), which translates something like "The Germans' work in Rio Grande do Sul" or "The industry of the Germans in Rio Grande do Sul", contains a brief description of a noteworthy episode in which rumors circulated of a slaves' revolt that 
would march on the town of São Leopoldo, leading a fair proportion of the region's colonists to arm themselves against the supposed rebellion.

Notwithstanding, some slave labor was used in the Germans colonies, despite laws prohibiting this. One example is law 183, promulgated on 13 October of 1850 , and stating that

[...] slaves who have been brought to the colonies, in contravention of this law, will be expelled by order of the Director, with costs to be paid by the owners of same slaves (Porto 1934, p. 229, our translation).

Also in 1850, Dr. João Daniel Hillebrand, commandant of the São Leopoldo colony and leader of the colonists who had allied with the liberal forces, informed the president of the Province, soon after the end of the Farroupilha revolution, that slavery

[...] has increased a little and in this region alone there are now 229 slaves, going on to state that this was too large a number for a district that has so many free hands; there is much need of a law that entirely prohibits bringing slaves into the colonial districts of the Province (Hillebrand apud Porto, 1934, p. 229, our translation).

We have discussed black work in an earlier publication (Nunes et al., 2013), showing that there were a considerable number of black workers involved in founding the region's leather industry. Anthropological research conducted from 2010 to 2012 illustrates the extent to which the relationship between work in the tanneries and settlement of the Sinos valley by blacks over the twentieth century is an intrinsic one.

Among blacks, experience with leatherwork, the "art of doing" (De Certeau, 1994), was transmitted from father to son, as one of our research informants narrates:

[...] our late departed daddy, he worked in a leather lacquer works where, at that time, the leather was lacquered manually, with a liquid, a paste, something like pitch, like this... This asphalt filler, you see? And they'd spread it on the leather with a spatula, you see? With sandpaper... First it was sanded, really smooth, you see? Then they would put that on with, with a hot paste, with a spatula. It was a terrible job, I remember that daddy sweated lots at one time, because that paste was hot, and he worked there. Until one day he got ill, couldn't work anymore, retired. But I think that was where my love for leather started. Before I was even born. (Sr. Valmor, August 2010, Source: Research project, The Black Communities in the Sinos Valley and the Memory of Work)

Intertwined with the Memory of Work are fragments of environmental memory from the old neighborhood known as "Africa", where a large part of the black population of Novo Hamburgo lived up until the first half of the twentieth century. Since the 1940s the neighborhood has been called Guarani and Sr. Alcides, one of our informants, who lives on the banks of the Guarani creek (running behind his house) describes what his childhood in the neighborhood was like:

What we most notice nowadays is that our childhood was freer, we had more freedom to do things, it was much less dangerous to do things and you weren't at as much risk as today. This neighborhood here where we are today [Guarani neighborhood, formerly called Africa], that little bit of forest there, that's virgin forest, all this here was. All of it. All of it virgin forest. There is a huge fig tree down here, this was all forest, we spent the day in middle of this forest, playing, eating fruit, eating other things, that there was our childhood (Sr. Alcides, 74 years old, 2010).

In dealing with the territorial occupation of the Sinos valley, one cannot neglect to consider class and ethnoracial distinctions because they dictate both the settlement of individuals in a given location and their urban itineraries. For example, there was the "Germans' neighborhood" (Hamburgo Velho), the "blacks' neighborhood" (Africa) and a neighborhood in which ethnic groups mixed, known as Mistura ("Mixture"). Mistura was located where the Rio Branco neighborhood is today. Recollections from one of our informants' give a clear idea of how the use of streams and creeks has transformed throughout the process of urbanization:

In those days Novo Hamburgo was, where our mother came to live, was called Mistura. From the bridge in that direction was Mistura, that was the name they gave it. And there it was almost all Germans. And we moved there, in the middle of all those Germans. But my mother could already speak German. We spoke German. After mother married father, we all spoke German. And then we went to live there. So there the people noticed, looked at us. It was a large family, mother's. There were 10 children. And we went to live there in a house. It was over there on that triangle in Rio Branco, after the Padaria Brasil bakers. There's a triangle for drivers, that's where our house was. The first house, right in the middle of all the Germans [laughter]. And it didn't make any difference because we spoke German. So we went to live there. And then my mother, back then, she started to be and she was... She came there straight from her first owners, you know... [the informant's mother had been a slave], she already knew how to cook, how to do the washing, she knew how to do everything. And so she started to work, to raise all her little black kids. She washed clothes, she ironed clothes, she was a cook, she was a housekeeper, she was a laundrywoman down at the stream. She washed clothes for the schools. In those days São Jacó [a school] had children living there, boarders at the college São Jacó. These boarders came from all over and lived 
there. And it was my mother who washed their clothes. It all came in bags. And we helped mother to bring the clothes to wash here in this creek [Luiz Rau] where they're going to do work soon, where that Tremsurb thing will pass. So, there we washed the clothes. Clean water. There we washed clothes all day, you know. It was more or less, from that point where there's that place for eating cold cuts, past the bridge, on the left there's a burger stall, where it gets full of cars, there's the Pio XII school and the Pica Pau. So it was in that "river" that we'd go to wash clothes. Mother washed, we already helped. We'd get out the clothes that were going to be bleached in the sun, it was all grass. She'd throw it up and we'd hang it out on the frame. We'd hang it out, whatever needed wringing, she'd throw it up to us, from the creek down there. When we had some free time, we'd get a hook and a rod, put the hook on... We used to wash clothes there, we used to fish there, we used to fry there and we used to eat there. My mother would wring the clothes there, there were some bricks and my mother would take some cans to boil the clothes in -in those days you boiled clothes - threw everything up, and she, down there, washing and throwing up what needed to be bleached, what needed boiling, what needed hanging out. And we'd do that work at the top, you know. And when we had a little free time, we'd go and fish there. We'd catch lambari. When I remember it seems like I'm making it up that we'd do that. I remember, but it sounds like I'm lying, nossa! That was our life, always washing clothes. Mother had São Jacó and Santa Catarina [schools]. So, for all of those boarders, it was my mother who did the washing. We lived there in the middle of the Germans. It was just us who lived there for years and years in the middle of the Germans. But because we spoke German, we got on well (Grandma Nair, 94 years old, 2012).

Over the course of thetwentieth century, and especially when footwear exports began to expand rapidly during the 1970 s, one of the techniques that was adopted to retain workers for the footwear factories was to allow people to occupy the river margins. In Novo Hamburgo, for example, urban expansion took place in the total absence of planning or environmental protection. The following recollections narrated by one of our informants help to illustrate this scenario:

And so the way the city was occupied, which was outside of the law, was influenced by the local government itself. We are not going to blame one side or the other. Neither the mayor's office nor the municipal Council. Not the Council as an institution, but the politicians, those who were Councilors at the time would find out from the mayor's office which areas were public and then persuade people: "build your house there, build your house there, build your house there". And so the mayor's office, which was unprepared and was not expecting that inflow, had to just look the other way, it didn't have the resources to go out to the housing put up in these areas, which sometimes was spontaneous and other times was planned. So the important point is that in Novo Hamburgo... Up until the 1990s, when we started to look into it deeper and tackle and develop the housing policy, Novo Hamburgo was seen as two cities, the regulated city and the unregulated city, or the legal city and the illegal city. The regulated city is made up of illegal city, with its planning maps, with all of its rules, following the building codes, all those kinds of things. And then there's the unregulated part which grew up in response to the needs of the people who came here to work. And this work really didn't make it possible for them, except in a state poverty, they didn't have access to, or the market didn't supply, housing that they could afford to pay with their wages - and I don't know if they would have managed it-which is how we see the structures of cities develop here, in the metropolitan centers. This process is not unique to Novo Hamburgo, other cities developed in the same way as well. Now, in terms of space, the city grew into the public areas. This unregulated city sprang up in exactly those areas that have been public: squares, road beds, the margins of highways - along this state highway, that strip we were talking about - and particularly along the banks of the rivers. (Public servant: municipal housing worker, 2006).

In summary, on the one hand, the environmental memory of Novo Hamburgo is built on the non-attribution of positive value to the previous colonial model based on extraction or to its forms of accumulation in terms of the environment impact caused by the agropastoral model associated with the Portuguese colonization of South Brazil, while on the other the industrial-laborer model's cult of the leather goods and footwear manufacturers and, more recently, its chemical and metalworking industries, has been impacting the many different dimensions of the region's land and water resources ever since its emergence|.

\section{The Environment and Public Participation in the Vale do Sinos - by Way of Conclusions}

Within the controversial context of the environmental memory of the Sinos valley and its dialogue with the field of political ecology and with studies of environmental conflicts, it is important to point out the fragility of the "communitary model" in the debate on environmental issues in the region where it relates to the environmental impact on the Sinos River Hydrographic Basin suffered 
over the course of the process of the development and maintenance of the leather goods and footwear industry, including when it was in crisis, in the mid-1990s.

Svampa (2011) has reflected on the macro level policies of neoliberal capitalism from the perspective of Harvey's concept of "accumulation by dispossession", calling attention to the new capital flows and movements that put the environment and territory at the center of the dispute.

The accumulation by dispossession model is founded on economic expropriation, on destruction of territories and on environmental plunder (Svampa, 2011, p. 184, our translation).

The new "eco-territorial flows" - giro ecoterritorial - have provoked large-scale protests in defense of biodiversity, traditional peoples and natural resources, which leads Svampa to conclude that through these socio-environmental movements the trend is to the consolidation of the foundations for an "eco-community flow".

Leite Lopes (2006) has also adopted an approach emphasizing environmental perspectives within the contemporary scenario, calling attention to the growth of the environmental debate in Brazil over recent years, which he claims is causing a certain discomfort in certain sectors of the economy, especially those that are "socially and environmentally predatory". Lopes believes we are seeing an "environmentalization of social conflicts".

\begin{abstract}
On the other hand, in parallel with the rise to prominence of environmental issues and the advance of environmental movements, the very entrepreneurs who are the main culprits of environmental degradation attempt to take ownership of the criticisms of their activities and use it to their own advantage. The field of business begins to be split between the pole of primitive environmental accumulation and the pole that is appropriating criticisms, the pole of "environmental responsibility" and even of production methods oriented to making clean and environmentally correct production feasible, which brings with it new material and symbolic gains. Between these two poles lie the pragmatic practices that alternate between using elements characteristic of one of the two opposing ideal pole types as part of their strategies in the field. Both workers and sections of the populations affected by environmental damage also begin to make use of environmental issues as a part of their repertoires of interests and demands (Lopes, 2006, p. 32, our translation).
\end{abstract}

Notwithstanding the interpretative originality of the authors cited above, they appear to converge on the idea of a growth in interest in environmental issues in Latin America over recent years. However, it must be borne in mind that, here in Brazil, a "politics of rights" emerged, gaining particular momentum at the end of the 1980s when the return to democracy after dictatorship was accompanied by intense social mobilizations in favor of recognition of collective identities and by demanding and winning rights, one which is the right to live in a sustainable environment. For example, superimposed on the "eco-territorial flows" and the "environmentalization of conflicts", there is also an "ethnicization of social struggles and urban landscapes", which was identified by Nunes (2009) after analysis of affirmative action policies in contemporary Brazil.

While these authors recognize the important roles fulfilled by these collective actors in the confrontations and dialogue with the State, the business sector and other social actors, the conflicts reveal the extent to which formulation, proposal and execution of public policies remain fragile, as does public participation in discussion of problems and decision-making processes.

With relation to the specific case of environmental policies in the Sinos valley, it is worth emphasizing that the fragility of this communitary model contributes to maintenance of environmental risks, such as the water contamination found in the area by Robaina, Formoso and Pires (2002), who detected heavy metals including zinc, copper, lead and chrome. Their study clearly shows the results of the combination of the highly polluting techniques used in the leather treatment processes developed by the leatherwork industrial-laborer model and in the processes used by the metalwork and chemical industries that have also been established in the Sinos valley.

Additional, very up-to-date evidence is reported by Nascimento (2014), whose research highlights the significant changes wrought on the waters of the Sinos river by discharge of domestic effluents without proper treatment.

This scenario is linked to urban growth of middle-class neighborhoods in combination with failure of local public authorities to attend to providing sewers of treatment of the water to supply the city and to the absence of effective public policies for management of the solid waste that the cities in the Sinos valley region produce.

For a long time the prosperity of the industries in the Sinos valley was linked to an absence of market rationality with regard to use of natural resources. The contamination of water resources is the result of a number of different harmful factors, including the leather goods and footwear industries, urban growth and domestic effluents, production of solid waste and the pollution of the smaller water courses with heavy metals, as is the case of the Luiz Rau and Pampa creeks, in Novo Hamburgo, and the Schmidt creek, in Campo Bom, both of which discharge into the Sinos river.

For some authors, such as Martínez-Alier (2004), situations such as the one described above can give rise to what he describes as "environmentalism of the poor or popular environmentalism", i.e., the emergence of social conflicts in which the dispossessed and marginalized take a conservationist stance, positioning themselves against growth and in favor of development with "environmental justice".

However, in the course of fieldwork conducted in 2012 and 2013 for the production of two documentaries, directed by Ana Luiza Carvalho da Rocha (2013a, b), on the condition of four creeks in the Sinos River Hydrographic Basin, we observed a very different situation to that described by Martínez-Alier (2004). We witnessed the "dispossessed" (HARVEY,2004) of a large number of workers who had been brought to the city and settled on the margins 
of the creeks and streams of the Sinos valley and in its wetlands because of the political and economic model of accumulation adopted by the leather industry, which has since its inception been associated with destruction and degradation of territories marked for environmental preservation and conservation and their water courses and foothills, with ill effects for the public health of the inhabitants of the large cities in the region.

Both "environmentalism of the poor" (Martínez-Alier, 2004) and the "eco-communitary flow" (Svampa, 2011) are far from the realities of the Sinos Valley. In our view, market logic still prevails over defense of natural resources.

\section{References}

BALANDIER, G., 1993, A noção de situação colonial. Translated from the French by Nicolás Nyimi CAMPANÁRIO. Revista Cadernos de Campo, vol. 3, no. 3, pp. 107-131.

COMITE DE GERENCIAMENTO DA BACIA HIDROGRÁFICA DO RIO DOS SINOS - COMITESINOS, 2015 [viewed 17 January 2015]. Caracterização da bacia. [online]. Available from: http:// www.comitesinos.com.br/bacia-hidrografica-do-rio-dos-sinos/ caracterizacao-da-bacia

DE CERTEAU, M., 1994. A Invenção do cotidiano. Artes de fazer. Petrópolis: Vozes.

DEVOS, R. V., 2007. A questão ambiental sob a ótica da antropologia dos grupos urbanos, nas ilhas do Parque estadual Delta do Jacuí, Bairro Arquipélago, Porto Alegre,RS. Porto Alegre: Universidade Federal do Rio Grande do Sul, 275 p. PhD Thesis in Social Anthropology.

DEVOS, R.V., SOARES, A.P.M. and ROCHA, A.L.C., 2010. Habitantes do Arroio - memória ambiental das águas urbanas, 2010. Desenvolvimento e Meio Ambiente, vol. 22, pp. 51-64.

HARVEY, D., 2004 [viewed 17 January 2015]. El 'nuevo' imperialismo: acumulacion por despossesion. In: L. PANITCH and C. LEYS, eds. El nuevo desafio imperial [online]. Buenos Aires: CLACSO. Socialist Register, no. 2004. Available from: bibliotecavirtual.clacso.org.ar/ar/libros/social/harvey.pdf

ISABELLE, A., 2006. Viagem ao Rio da Prata e ao Grande do Sul-1833-1834. Brasília: Edições do Senado Federal.

LOPES, J.S.L., 2006. Sobre processos de "ambientalização" dos conflitos e sobre dilemas da participação. Horizontes Antropológicos, vol. 12 , no. 25 , pp. 31-64.

MARTÍNEZ ALIER, J., 2004. El Ecologismo de los Pobres: conflitos ambientales y linguajes de valoracion. Barcelona: Icaria Editorial.
NASCIMENTO, C.A., 2014, Uma proposta de índice de qualidade de água como ferramenta de apoio a gestão de estações de água para consumo humano. Novo Hamburgo: Universidade Feevale. $\mathrm{PhD}$ Thesis in Environmental Quality.

NUNES, M.F., 2009. "O negro no mundo alemão": cidade, memória e ações afirmativas no tempo da globalização. Florianópolis: Universidade Federal de Santa Catarina, 255 p. PhD Thesis in Social Anthropology.

NUNES, M.F., ROCHA, A.L.C., MAGALHÃES, M.L. and KUHN JUNIOR, N., 2013. "Era um hino de fábrica apitando": a memória do trabalho negro na cidade de Novo Hamburgo (RS), Brasil. Etnográfica, vol. 17, no. 2, pp. 269-291. http://dx.doi. org/10.4000/etnografica.3122.

PETRY, L., 1944. O município de Novo Hamburgo. Porto Alegre: Edições A Nação.

PORTO, A., 1934. O trabalho alemão no Rio Grande do Sul. Porto Alegre: Editora e Gráfica Terezinha.

QUIJANO, A., 2000. "Colonialidad del poder y clasificación social”. Journal of World-System Research, vol. 2, pp. 342-386.

ROBAINA, L.E., FORMOSO, M.L.L., PIRES, C.A.F., 2002. Metais Pesados nos Sedimentos de Corrente, como Indicadores de Risco Ambiental - Vale do Rio dos Sinos, RS. Revista do Instituto Geológico, vol. 23, no. 2, pp. 35-47.

ROCHA, A.L.C., 1994. Le Sanctuaire du Desordre, ou l'art de vivre des tendres barbares sous les Tristes Tropiques. Estude de l'esthétique urbaine e la mémoire collective au sud du Brésil. Paris: Université René Descartes, 921 p. Doctoral Thesis in Sociology.

ROCHA, A.L.C., NUNES, M.F., TUNDISI, J.G., RODRIGUES, M.A.S., 2013a. Um panorama da qualidade das águas na Bacia do Rio dos Sinos - poluição e impactos ambientais. Novo Hamburgo: Feevale/IIEGA/Instituto Anthropos. Documentário etnográfico.

ROCHA, A.L.C., NUNES, M.F., TUNDISI, J.G., RODRIGUES, M.A.S., 2013b. Os Arroios não estão errados - conflitos de usos das águas urbanas no Rio Grande do Sul. Novo Hamburgo: Feevale/IIEGA/Instituto Anthropos. (Documentário etnográfico).

SCHEMES, C., 2006. Pedro Adams Filho: empreendedorismo, indústria calçadista e emancipação de Novo Hamburgo (19011935). Porto Alegre: Pontifícia Universidade Católica do Rio Grande do Sul, 446 p. Doctoral Thesis in History.

SVAMPA, M., 2011. Modelos de desarrollo, cuestion ambiental y giro eco-territorial. In: H. ALIMONDA, coord. La Naturaleza Colonizada. Ecologia política y mineria en America Latina. Buenos Aires: Ediciones Ciccus. 